\title{
IMPROVING THE MECHANISM OF PREFERENTIAL LENDING TO AGRICULTURAL ENTERPRISES OF UKRAINE
}

\author{
Elena LEMISHKO ${ }^{1}$ \\ National University of Life and Environmental Sciences of Ukraine, Ukraine
}

\begin{abstract}
Basic tools of the mechanism of preferential lending to agricultural enterprises of Ukraine are considered in the article. The analysis of state and dynamics of lending to agricultural enterprises for the period 2001-2014 are done. The accent of attention on the need of state regulation intensification of the formation of an effective mechanism of preferential crediting to agricultural enterprises is marked. Methods. In the article are used tabular, graphical and statistical methods for economic research. Information base of research are legislative and legal acts, which regulate activity of agricultural enterprises, report data from the Ministry of Agrarian Policy and Food of Ukraine, the Annual Report of the National Bank of Ukraine, the State Statistics Service of Ukraine, taxed financial statements of agricultural enterprises, the results of own research. Results. In the process of research, it was found that effectiveness of crediting, primarily, determined by the validity of credit policy, effectiveness of the key factors of credit mechanism and macro-financial stability of the state. It is found that the mechanism of preferential lending to agricultural enterprises in Ukraine was not optimized and perfected at the appropriate level throughout the study period, the volume of direct support to agricultural production, which is also preferential loans to agricultural enterprises, were insufficient. Practical meaning. It is proved that improve of the mechanism of preferential lending to agricultural enterprises should be based on optimizing the needs of the state, borrowers (subjects of the agricultural sector), lenders (banks and non-bank institutions) and financial market regulators. Value/originality. Ways to improve the mechanism of preferential lending to agricultural enterprises by creating appropriate institutional framework to support agro-industrial complex, intensification of cooperation of agricultural enterprises and banking institutions to solve mutual interests, ordering a credit quality for agricultural enterprises and through improving the legal component of the preferential lending mechanism is provided. It is stated in conclusions that there is need for further research of these problems.
\end{abstract}

Key words: mechanism of preferential lending, agricultural enterprises, banks, organizational and legal part of the loan mechanism, macro-financial stability of the state, lending efficiency.

JEL Classification: G210, G320, H810, Q140

\section{Introduction}

Agricultural dialogue between Ukraine and the EU on cooperation was initiated in 2006. It is still extremely important to expand access of Ukrainian agricultural producers through the future association agreement and a free trade zone with the EU market. But Ukraine's aspiration for integration into the European Union should be based on the development of measures and mechanisms for sustainable development of agriculture sectors, increasing agricultural production and adaptation of its quality to international standards (as the main factor of competitive ability), which requires additional investment of material and financial assets. A significant source of financial assets and financial resources is credit support. However, considering that in fact the agricultural sector is resource intensive sphere, which, moreover, is characterized by considerable duration of the production

Corresponding author:

${ }^{1}$ Department of Taxation and Insurance, National University of Life and Environmental Sciences of Ukraine.

E-mail: elena.lemishko@gmail.com cycle and a significant period of funds rotation, there is an urgent need to allocate stable sources of resources defined to ensure the production cycle on qualified, high technology level (Popov, 2012). The source of such resources is a bank lending, whose stability can be achieved by implementation of an effective mechanism of financial support of agricultural enterprises by the state through the use of preferential lending.

\section{State and dynamics of preferential lending to agricultural enterprises of Ukraine}

Effectiveness of agricultural enterprises in Western Europe and the US are caused by symbiosis of commercial crediting institutions (commercial banks, associations, credit unions, insurance companies, etc.) and balanced system of state financial support of the agricultural economics sector. Free access of farmers to sources of 
capital, specifically, to credit resources, furthers apparent progress in providing economic interests of subjects of agricultural sector of leading countries. The objective availability of high needs of loans by farmers in Ukraine (compared to other sectors of the economy) is not fully covered by imperfect credit facilities and high cost of credit resources. Search for the trends of cheaper loans defined partial compensation of interest rates due to the budget as the main tool for effective financial and credit mechanism to support the agricultural sector of Ukraine. Since 2000, Ukraine has implemented a state program to support the income of agricultural enterprises through compensation from the state budget of interest rates on loans of commercial banks obtained by agricultural producers. Agricultural enterprises have acquired the right to freely choose the lending bank, which agreed to provide a loan under the passport of banking products and terms of compensation from the state budget of a part of interest rates on of commercial banks' loans.

In 2001 the state compensated commercial lending rates at the rate of $70 \%$ discount rate of the National Bank of Ukraine. State support for credit support of agricultural sector significantly increased the interest of banking to agriculture; the flow of credit from commercial banks to agricultural producers has increased significantly, which positively affected the efficiency of agricultural production. Analysis of state and dynamics of lending to agricultural enterprises (table 1) shows that during 20012014 there is a constant growth of rates of loans to the agricultural sector of Ukraine - from 5.9 to $14.7 \mathrm{bln}$. UAH.
However, this trend was volatile and should be divided into the following three periods: 2001-2008, 20092012, 2013-2014.

First period of 2001-2008 is characterized by economic transformations, creation of market principles of functioning and development of the state economy and the agricultural sector in particular. Gradually increased the gross output of agricultural sector, which was a result of ownership change with the organizational restructuring of enterprises, formation of new rural organizational and legal structures of market type (because of the principles of agrarian reform realization, which, in particular, was adopted on 03.12.1999 by Decree of the President of Ukraine "On Urgent Measures to Accelerate Reform of Agricultural Sector"). Positive dynamics of profitability was accompanied by an increase in the efficiency of agricultural production, increased the level of financial stability and creditworthiness of agricultural enterprises. The cooperation of banks and agricultural sector has been strengthening, and using the budget as an effective tool of financial and credit support mechanism made possible to obtain preferential loans of $15.1 \mathrm{bln}$. UAH to the agricultural sector in 2008, which exceeded the level of 2001 in 5,4 times.

In 2009 the world economy was in a state of recession, which prevented the creation of a post-crisis Ukraine basis for sustainable economic recovery. The period of 20092012 for Ukraine's economy in general and the agricultural sector, in particular, can be described as a slow economic recovery after the financial crisis of 2008, increasing the

Table 1

State of lending to agricultural enterprises of Ukraine for 2001-2014 bln. UAH

\begin{tabular}{|l|c|c|c|c|c|c|c|c|c|}
\hline \multirow{2}{*}{ Indicators } & \multicolumn{7}{c|}{ Year } \\
\cline { 2 - 9 } & 2001 & 2005 & 2008 & 2009 & 2010 & 2011 & 2012 & 2013 & 2014 \\
\hline Volume of loans - total & 5,9 & 10,4 & 20,1 & 6,7 & 10,1 & 14,9 & 13,5 & 16,2 & 14,7 \\
\hline among them: & & & & & & & & \\
\hline Short-term & 5,6 & 6,6 & 10,3 & 4,9 & 7,0 & 10,3 & 9,6 & 9,9 & 10,8 \\
\hline including specific weight, \% & 94,9 & 63,5 & 51,3 & 73,2 & 69,3 & 69,1 & 71,1 & 61,1 & 73,5 \\
\hline Medium-term & 0,3 & 3,8 & 6,5 & 1,2 & 1,4 & 2,8 & 2,3 & 3,1 & 2,2 \\
\hline including specific weight, \% & 5,1 & 36,5 & 32,3 & 17,9 & 13,9 & 18,8 & 17,1 & 19,2 & 14,9 \\
\hline Long-term & - & - & 3,3 & 0,6 & 1,7 & 1,8 & 1,6 & 3,2 & 1,7 \\
\hline including specific weight, \% & - & - & 16,4 & 8,9 & 16,8 & 12,1 & 11,8 & 19,7 & 11,6 \\
\hline Received preferential loans - total: & 2,8 & 7,6 & 15,1 & 2,6 & 6,2 & 4,1 & 1,3 & 1,1 & 1,4 \\
\hline among them: & & & & & & & & & \\
\hline Short-term & 2,8 & 4,8 & 9,1 & 2,3 & 4,5 & 3,3 & 0,8 & 0,6 & 0,9 \\
\hline including specific weight, \% & 100,0 & 63,2 & 60,3 & 88,5 & 72,6 & 80,5 & 61,5 & 54,5 & 64,3 \\
\hline Medium-term & - & 2,8 & 3,7 & 0,2 & 0,6 & 0,7 & 0,4 & 0,4 & 0,3 \\
\hline including specific weight, \% & - & 36,8 & 24,5 & 7,7 & 9,7 & 17,1 & 30,8 & 36,4 & 21,4 \\
\hline Long-term & - & - & 2,3 & 0,1 & 1,1 & 0,1 & 0,1 & 0,1 & 0,2 \\
\hline including specific weight, \% & - & - & 15,2 & 3,8 & 17,7 & 2,4 & 7,7 & 9,1 & 14,3 \\
\hline Transitive preferential loans & - & - & 6,1 & 12,8 & 6,5 & 6,7 & 9,8 & 4,1 & 6,1 \\
\hline Funds in state budget for cheaper loans & 0,1 & 0,4 & 1,3 & 1,1 & 0,6 & 0,6 & 0,4 & 0,2 & 0,3 \\
\hline In fact compensated by state budget & 0,1 & 0,4 & 1,1 & 0,4 & 0,6 & 0,6 & 0,3 & 0,1 & 0,2 \\
\hline $\begin{array}{l}\text { Number of enterprises which involved } \\
\text { loans (units) }\end{array}$ & 5024 & 13044 & 9409 & 2231 & 2238 & 2668 & 2603 & 3142 & 2547 \\
\hline
\end{tabular}

Source: Calculated by the author according to the Ministry of Agriculture and Food 
role of credit mechanism in the lending system of economic agents, and increasing the productivity of using credit resources as capital of enterprises. Despite the depressed trend in industry (industrial output fell by $21.9 \%$ in 2009 compared to 2008) and construction (amount of work is declined by $48.2 \%$ ), slowing credit growth annualized in these sectors of economy was significantly slower pace than in agriculture, where production did not decrease over the previous year. Unfortunately, the downward dynamics of lending was the most fleeting thing in the agrarian sector, if in the previous period (2001-2008) annual lending increased; in 2009 they decreased almost 3 times on the level of 2008 and amounted to $6.7 \mathrm{bln}$. UAH. This trend has been due to the increased requirements for loans against the background of reducing the creditworthiness of farmers and low investment agricultural sector. Deceleration of inflation in the country had been moderated and the effect transfer from the devaluation of hryvnia to catastrophic prices had been created (in 5.8 times) reduced government funding of credit programs of agricultural sector. Besides, if while the period of 2001-2008 the amount provided in the state budget for compensation of interest rates were fully spent, in 2009 their actual payment was only $36 \%$. As a result - the number of enterprises that attracted loans in the current year decreased 4 times (to 2,231 units) and for the entire study period, including 2014, never reached the level of 2008 ( 9408 units) and kept at the level of 2009.

At the beginning of 2012 Ukraine was not yet capable for real anti-crisis stability in the global environment and independent of global trends of development. Thus, a significant openness of the national economy and subordination of the leading sectors (including agriculture) to foreign market, against the background of high-level crisis expectations, renovation of recession trends in some European countries and slowdown of the global economy during the year, significantly influenced the decline in economic growth of our country. The volume of preferential lending to agricultural enterprises of Ukraine in 2012 ( $1.3 \mathrm{bln}$. UAH) was only a tenth of the total volume of loans. The third phase (2013-2014) for Ukraine is characterized as stage deployment of political and another economic crisis: increasing of debt financing, growing budget deficits, no recovery of main capital, import growth prevailed in exports and factor of not payback of investment costs in Euro 2012 were the main crisis factors of 2013. However, it should be emphasized that the increase in financial support to farmers by banking sector was one of the main factors of sustainable dynamic development of agriculture in 2013: 19.3\% increase in the volume of loans (to $16.2 \mathrm{bln}$. UAH) granted by banks to business management in agriculture (against 6.9\% in 2012$) ; 13.7 \%$ increase in the volume of agricultural production (to it reduce $4.5 \%$ in 2012 ) to $308.1 \mathrm{bln}$. UAH; It has been received $1.1 \mathrm{bln}$. UAH of preferential loans.

2014 was a breaking point for political and economic changes in our country and simultaneously launched the most serious test for Ukrainian society. The credit activity of banks collapsed in 2014 that influenced the following factors: firstly, the political tension in the country; secondly, the reduction of state funding, a significant reduction of the solvency and creditworthiness of borrowers, reducing the resource and the deposit base of banks; thirdly, significant destabilizing fluctuations of hryvnia to foreign currencies. Against the background of decline of basic industries of Ukraine (9.6\% per year), only the agricultural industry increased production and export of its products and finished 2014 with a gain, which amounted to $2.8 \%$ per year. In the context of forced (through external aggression against Ukraine) closing up of foreign economic activity, decline in exports of goods and services by $14.6 \%$ in 2014 was marked by a revolutionary event, which had a positive impact on ease of complex macroeconomic situation in Ukraine and its significant improvement in agriculture sector, particularly: 23 April of 2014 as effective date for Ukraine of unilateral cancellation fees regime with the EU, which liberalized access, primarily of agricultural products of Ukraine to European markets. The dynamics of lending to agriculture in 2014 was determined by the general state vector of credit facility: the volume of loans to agricultural enterprises in 2014 totalled 14.7 bln. UAH, preferential loans - 1.4 bln. UAH.

\section{Efficiency of lending to agricultural enterprises of Ukraine}

To maintain revenue of agricultural enterprises of interest rates by loans to commercial banks obtained by agricultural producers were compensated by the state budget. For the period of 2001 - 2014 interest rates that were compensated to state agricultural enterprises at preferential loans in Ukraine, average 9.5\% (Fig. 1).

Active providers of credits to agribusinesses at the end of 2014 became the following banks: PJSC "Credit Agricole Bank", PJSC "ProCredit Bank", OJSC "Alfa-Bank", OJSC "Raiffeisen Bank Aval", PJSC "Ukrsotsbank» (UniCredit Bank), PJSC "UkrSibbank", PJSC "Privatbank", OJSC "State Savings bank of Ukraine" (Oshchadbank). According to various estimates, the share of bank lending in Ukraine occupies less than $20 \%$ of working capital of agrarian sector, while in developed countries it is $70 \%$; rate on loans to agriculture at the end of February 2016 was $19.8 \%$, exceeding the average interest rate on loans to the economy (16.4\%) (Danylyshyn, 2016). Efficiency of lending is primarily determined by the validity of credit policy, effectiveness of key factors of credit mechanism and macro-financial stability of the state. Considering that in 2014 in Ukraine political crisis led to financial, economic and banking crisis during 2014 and next 2015, access to lending to agricultural enterprises had been limited.

Also, accumulated in previous years, macroeconomic imbalances destabilized financial base and negatively influenced the state budget. That is why, the amount of budgetary funds on financial support to measures in the agrarian sector through cheaper loans for 2015 and 


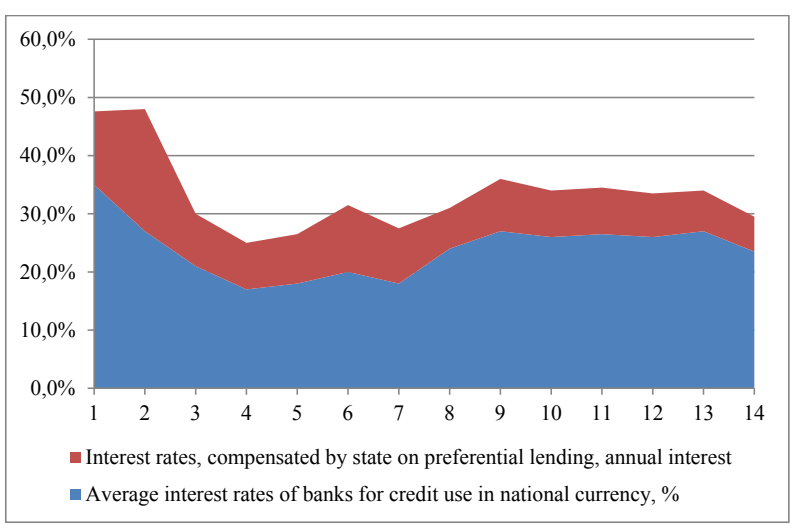

Fig. 1. Relative indicators of state of lending to agricultural enterprises of Ukraine

Source: Calculated by the author according to the Ministry of Agriculture and Food, the Bulletin of the National Bank of Ukraine

2016 remains at almost 2014 level (by the law on the State Budget of Ukraine for 2016 provided for the event $300 \mathrm{mln}$. UAH, in 2015 actual budget of funding in this area amounted to $290.6 \mathrm{mln}$. UAH). However, it should be emphasized that Ukraine is on the one of the last places among European countries on the total support of the agricultural sector: the figure in the European Union in 2013-2014 was nearly 60 bln. euros annually, which is about 525 euros/ha or $20 \%$ of gross agricultural output, while in Ukraine this figure poised between 10-20 euros/ha (Danylyshyn, 2016).

Gross output per unit of credit resources invested in the agricultural sector is characterized by a steady decline of this indicator during the study period (from 99.05 to 4.54 UAH of the value of the produced gross output for 1 UAH of credit resources) (Table 2).

Research of lending efficiency of agricultural enterprises (net profit) showed better effectiveness: dynamics of growth of this indicator was positive, which impact exceeding the growth rate of net income of agricultural enterprises on the rate of growth in bank lending. Thus, in 2014 hryvnia for each credit received 1.46 UAH net profits. The effectiveness of state support of agricultural enterprises' credit support characterizes by coefficient of multiplier that shows the ratio of issued preferential loans to the amount of compensation for interest rate from the budget; its highest value (54.8\%) was in 2012, the lowest in 2011 (6.7\%).

To further analysis of the impact of the budget funds allocated to reduce the cost of loans to the volume of preferential lending to agricultural enterprises is used Anna Isayan's method that proves the hypothesis about linear dependence of lending of the amount of budgetary funds (Isayan, 2013, p.69). According to this method, the rate of effectiveness of each budget hryvnia spent on cheaper loans is calculated as the ratio of annual volume of preferential lending to the budget. The average value of this indicator over the period $2001-2014$ is, according to our calculations, 10,17 UAH, but the volatility is quite high: if in 2001 every hryvnia allocated from the state budget provided to obtain credit facilities in the amount of 28.0 UAH, in 2014 -total - 4,7 UAH. Thus, the mechanism of preferential lending to agricultural enterprises of Ukraine was not optimized and perfected at the appropriate level throughout the study period, the volume of direct support to agricultural production, which, including preferential loans are agricultural enterprises, were insufficient. Among the reasons for this negative situation must be specified the following: chronic budget deficit and imperfect legal framework of procedures for preferential loans; financing of state programs to support the agricultural sector is a residual; banks typically provide funding only to those agricultural enterprises that have more than 100 hectares of land, smaller companies are unable to obtain loans and preferential financing. We believe that the mechanism of preferential lending to agricultural enterprises, firstly, has no clear targeting of channelling funds and exclude counter cash flows; secondly, the absence of guarantee of stability at the national level and predictability of agricultural policy leads to unjustified change of the preferential lending support mechanism almost every year; thirdly, by intervention of the administrative factor to budget allocation have been cases of corruption, which caused the

Table 2

Efficiency of lending to agricultural enterprises of Ukraine for 2001-2014

\begin{tabular}{|c|c|c|c|c|c|c|c|c|c|}
\hline \multirow{2}{*}{ Indicators } & \multicolumn{9}{|c|}{ Year } \\
\hline & 2001 & 2005 & 2008 & 2009 & 2010 & 2011 & 2012 & 2013 & 2014 \\
\hline \multicolumn{10}{|c|}{ Indicators of lending efficiency } \\
\hline Loan return & 99,05 & 21,93 & 7,0 & 7,61 & 7,34 & 6,85 & 6,12 & 5,81 & 4,54 \\
\hline Lending efficiency & 0,12 & 0,34 & 0,29 & 1,13 & 1,71 & 1,70 & 1,98 & 0,92 & 1,46 \\
\hline \multicolumn{10}{|c|}{ Indicators of efficiency of state support of lending to agricultural enterprises } \\
\hline $\begin{array}{l}\text { Share of preferential loans to total } \\
\text { loans, \% }\end{array}$ & 47,5 & 73,1 & 75,1 & 38,8 & 61,4 & 27,5 & 9,6 & 6,8 & 9,5 \\
\hline Coefficient of multiplier & 20,8 & 18,4 & 14,8 & 6,8 & 9,9 & 6,7 & 54,8 & 15,7 & 23,3 \\
\hline $\begin{array}{l}\text { Efficiency of budget funds, spent on } \\
\text { cheaper loans }{ }^{1}\end{array}$ & 28,0 & 19,0 & 11,6 & 2,4 & 10,3 & 6,8 & 3,25 & 5,5 & 4,7 \\
\hline
\end{tabular}

Source: Calculated by the author according to the Ministry of Agriculture and Food, the Bulletin of the National Bank of Ukraine

${ }^{1}$ Calculated by the method of Anna Isayan 
efficiency of key factors of agricultural producers' support mechanism to nothing.

\section{Conclusions}

The mechanism of preferential lending to agricultural enterprises still remains today the main tool for increasing the availability of credit resources to the agricultural sector. We believe that improving the mechanism of preferential lending to agricultural enterprises should be based on optimizing the needs of the state, borrowers (of the agricultural sector of economy), lenders (banks and non-bank institutions) and financial market regulators. To improve the mechanism of preferential lending to agricultural enterprises we propose the following: first, an institutional framework to support agriculture must be created, namely, banks (and perhaps non-bank institutions) with industry specialization in service of agricultural enterprises and required state share of property. Considering that the implementation of this proposal into practice requires global finance and fairly long period of time, we propose in the near future to create in banks, which currently have a positive experience of cooperation with farmers, separate units to address the key financial issues related to the agricultural sector of economy. The cogent condition for this should be constructive cooperation of bank employees and specialists of agricultural sector for the most thorough account of the specific characteristics of the industry and in the performance of lending procedures.

Second, help of agrarians in accession of banks' resources base: cooperation of agricultural enterprises and banking institutions should be based on solving mutual interest, in particular, considering that external problems of 2014 still negatively affects the resource base of banks (as evidenced by the analysis of liabilities of the banking system of Ukraine), a comprehensive program to attract cash balances of enterprises of agrarian sphere on deposit banks' accounts must be developed. In this case, we consider it appropriate to provide the status of special assistance in obtaining loans by those entities of agriculture that have deposit accounts in this bank.

Third, systematization of credit quality for agricultural enterprises: clear continuous periodization of the agricultural production process, the slow circulation of capital required to attract credit resources for long periods, that is, long-term lending. But considering that agricultural sector refers to the high-risk area (through natural factors that are closely associated with the process of reproduction in agriculture and natural phenomena), there is an increased risk for banking institutions to delayed repayment or failure to return the loan. We believe that in this case, partial mechanism (not less than 50\%) must be fully involved or optimally full state guarantee of the repayment of long-term loans for agricultural enterprises.

Fourth - to improve the legal component of the mechanism of preferential loans and, again, given that agriculture is a high risk (there is the risk of delayed repayment or loan default) requires banking institutions, which will apply to the National Bank of Ukraine to refunding, allow agricultural enterprises, which of objective circumstances are unable to timely repay the loan on short-term credits, by short term attraction to extend the credits no less than for one year, and on long-term (five years) - not less than for two years. Furthermore, there is a need to optimize the procedure for obtaining preferential lending procedure; today for reimbursement of the interest on the loan farmer must provide a competitive commission up to 15 documents that greatly complicates the entire organizational cycle of getting preferential loans.

An important condition for intensification of bank lending to the agricultural sector is cooperation between Ukraine and the EU member states to exchange of experience on stage associated membership in the EU, including through the introduction of a system of agricultural subsidies and preferential loans to support production, improve competitiveness and efficiency of agricultural production. Considering that today in Ukraine there is a need to limit public deficits and synthetic cuts in public spending on recovery programs and economic development, the introduction of subsidies and preferential loans, including in agriculture, to expand the range of credit sources, depending on the creditworthiness of the borrower, increase agricultural cooperation with market financing. It is especially emphasized that the mechanism of preferential lending is only a tool for achieving the strategic goal - the formation of creditworthy, competitive, financially sustainable, profitable borrower - the entity of agrarian sector of Ukraine.

\section{References}

Danylyshyn, B. New state support of agroindustrial complex - way to nowhere. Retrieved from: http://economics.lb.ua/state/2016/04/07/332278_nova_derzhavna_pidtrimka.html.

Decree of the President of Ukraine (1999). On Urgent Measures to Accelerate Reform of Agricultural Sector. Golos Ukrayiny. 227 ( 7 Dec).

Ministry of Agrarian Policy and Food of Ukraine. Retrieved from: http://minagro.gov.ua/

National Bank of Ukraine (2014). Bulletin, 1.

National Bank of Ukraine. Official website. Retrieved from: http://bank.gov.ua

Oliynyk, O.O. (2014). Financial and credit system of the agricultural sector of Ukraine's economy: theory, methodology, practice. Kyiv: PC «KOMPRINT».

Popov, V.M. (2012). Modern features of financial security of agriculture. Scientific efforts of Kirovograd National Technical University. Economics, 22 (2), 163-169. 
Isayan, A.M. (2013). Preferential lending of enterprises of agroindustrial complex: theory and practice. Journal of University of Banking of National Bank of Ukraine, 1(16), 66-70.

R Core Team. (2014). R: A Language and Environment for Statistical Computing. Vienna, Austria: Author.

Siudek T. (2010). Polish cooperative banking sector in the face of systemic transformation and European integration in agriculture. Czech.

State Statistics Service of Ukraine. Retrieved from: http://www.ukrstat.gov.ua

\section{Елена ЛЕМИШКО}

\section{СОВЕРШЕНСТВОВАНИЕ МЕХАНИЗМА ЛЬГОТНОГО КРЕДИТОВАНИЯ АГРАРНЫХ ПРЕДПРИЯТИЙ УКРАИНЫ}

Аннотация. В статье рассмотрены основные инструменты механизма льготного кредитования аграрных предприятий Украины. Проведен анализ состояния и динамики кредитования аграрных предприятий за период 2001-2014 рр. Акцентировано внимание на необходимости активизации государственного регулирования формирования эффективного механизма льготного кредитования аграрных предприятий. Методика. В статье использовались табличный, графический и статистический методы экономических исследований. Информационную базу исследования составляют законодательные и нормативноправовые акты, регулирующие деятельность аграрных предприятий, отчетные данные Министерства аграрной политики и продовольствия Украины, Годового отчета Национального банка Украины, Государственной службы статистики Украины, данные финансовой отчетности сельскохозяйственных предприятий, результаты собственных исследований. Результаты. В процессе проведенных исследований было выявлено, что эффективность кредитования, в первую очередь, определяется обоснованностью кредитной политики, действенностью рычагов кредитного механизма и макрофинансовой стабильностью государства. Было установлено, что механизм льготного кредитования аграрных предприятий Украины не было оптимизировано и отработано на должном уровне на протяжении всего исследуемого периода, объемы прямой поддержки сельскохозяйственного производства, которым, в том числе является льготное кредитование аграрных предприятий, оказались недостаточными. Практическое значение. Доказано, что усовершенствование механизма льготного кредитования аграрных предприятий должно базироваться на оптимизации потребностей государства, заемщиков (субъектов аграрного сектора экономики), кредиторов (банковских и небанковских институтов) и регуляторов финансового рынка. Значение/оригинальность. Предложены пути совершенствования механизма льготного кредитования аграрных предприятий на основе создания соответствующей институциональной основы для поддержки агропромышленного комплекса, активизации сотрудничества аграрных предприятий и банковских учреждений для решения взаимных интересов, систематизации качества кредитов для аграрных предприятий, а также на основе улучшения организационно-правовой составляющей механизма льготного кредитования. В итоге констатируется, что существует необходимость дальнейших исследований в области выявленных проблем. 